\title{
Histoplasma capsulatum proteome response to decreased iron availability
}

\author{
Michael S Winters*1, Daniel S Spellman², Qilin Chan², Francisco J Gomez ${ }^{4}$, \\ Margarita Hernandez ${ }^{5}$, Brittany Catron ${ }^{3}$, Alan G Smulian ${ }^{4}$, \\ Thomas A Neubert ${ }^{2}$ and George S Deepe $\mathrm{Jr}^{1,4}$
}

\begin{abstract}
Address: ${ }^{1}$ Division of Infectious Diseases, University of Cincinnati College of Medicine, Cincinnati, OH 45267, USA, ${ }^{2}$ Department of Pharmacology and Kimmel Center for Biology and Medicine at the Skirball Institute, New York University School of Medicine, New York, NY 10016, USA, ${ }^{3}$ Department of Chemistry, University of Cincinnati, Cincinnati, OH 45221-0172, USA, ${ }^{4}$ Veterans Affairs Hospital, University of Cincinnati College of Medicine, Cincinnati, OH 45267, USA and ${ }^{5}$ Department of Biology, University of Texas at San Antonio, One UTSA Circle, San Antonio, TX 78249-006, USA

Email: Michael S Winters* - winterms@uc.edu; Daniel S Spellman - daniel_spellman@merck.com; Qilin Chan - qlchan@gmail.com; Francisco J Gomez - Gomezfj@uc.edu; Margarita Hernandez - flu273@my.utsa.edu; Brittany Catron - brittany.catron@gmail.com; Alan G Smulian - smuliang@fuse.net; Thomas A Neubert - neubert@saturn.med.nyu.edu; George S Deepe - Deepegs@uc.edu

* Corresponding author
\end{abstract}

Published: 24 December 2008

Proteome Science 2008, 6:36 doi:10.1186/1477-5956-6-36

This article is available from: http://www.proteomesci.com/content/6/1/36

(C) 2008 Winters et al; licensee BioMed Central Ltd.

This is an Open Access article distributed under the terms of the Creative Commons Attribution License (http://creativecommons.org/licenses/by/2.0), which permits unrestricted use, distribution, and reproduction in any medium, provided the original work is properly cited.

\begin{abstract}
Background: A fundamental pathogenic feature of the fungus Histoplasma capsulatum is its ability to evade innate and adaptive immune defenses. Once ingested by macrophages the organism is faced with several hostile environmental conditions including iron limitation. $H$. capsulatum can establish a persistent state within the macrophage. A gap in knowledge exists because the identities and number of proteins regulated by the organism under host conditions has yet to be defined. Lack of such knowledge is an important problem because until these proteins are identified it is unlikely that they can be targeted as new and innovative treatment for histoplasmosis.
\end{abstract}

Results: To investigate the proteomic response by $H$. capsulatum to decreasing iron availability we have created $H$. capsulatum protein/genomic databases compatible with current mass spectrometric (MS) search engines. Databases were assembled from the $H$. capsulatum G217B strain genome using gene prediction programs and expressed sequence tag (EST) libraries. Searching these databases with MS data generated from two dimensional (2D) in-gel digestions of proteins resulted in over $50 \%$ more proteins identified compared to searching the publicly available fungal databases alone. Using 2D gel electrophoresis combined with statistical analysis we discovered $42 \mathrm{H}$. capsulatum proteins whose abundance was significantly modulated when iron concentrations were lowered. Altered proteins were identified by mass spectrometry and database searching to be involved in glycolysis, the tricarboxylic acid cycle, lysine metabolism, protein synthesis, and one protein sequence whose function was unknown.

Conclusion: We have created a bioinformatics platform for $\mathrm{H}$. capsulatum and demonstrated the utility of a proteomic approach by identifying a shift in metabolism the organism utilizes to cope with the hostile conditions provided by the host. We have shown that enzyme transcripts regulated by other fungal pathogens in response to lowering iron availability are also regulated in $H$. capsulatum at the protein level. We also identified $H$. capsulatum proteins sensitive to iron level reductions which have yet to be connected to iron availability in other pathogens. These data also indicate the complexity of the response by $\mathrm{H}$. capsulatum to nutritional deprivation. Finally, we demonstrate the importance of a strain specific gene/protein database for $H$. capsulatum proteomic analysis. 


\section{Background}

Histoplasma capsulatum is a dimorphic fungus and the etiological agent of histoplasmosis. The fungus is endemic to the Midwestern and southeastern United States. H. capsulatum can be a life-threatening infection for individuals suffering from immune defects associated with AIDS and for those receiving immunosuppressive pharmaceuticals to combat malignancy, graft rejection, and autoimmunity. More recently, antagonists to tumor necrosis factor- $\alpha$ have been identified as a risk factor for the development of disseminated histoplasmosis [1-5].

H. capsulatum survives in the mammalian host by evading both the innate and adaptive immune responses. H. capsulatum is confronted by several phagocytic cell populations including immature dendritic cells, neutrophils, and macrophages. Among them, the last is the only professional phagocytic cell population in which $H$. capsulatum can replicate freely [6]. Intracellularly, $H$. capsulatum must confront and adapt to phagolysosomal fusion, nitrosative stresses, low nutrient availability, and low $\mathrm{pH}$ [7-12].

Two-dimensional electrophoresis in combination with mass spectrometry has become a powerful tool for studying the proteome of a number of intracellular pathogens [13-19]. There have been limited microarray and proteomic analyses of $H$. capsulatum [20-22]. For fungi such as $H$. capsulatum, such information is nascent. Therefore we have utilized the publicly available $H$. capsulatum G217B genome and transcripts developed for microarray analysis to construct protein/genomic databases compatible with mass spectrometry (MS) data search engines. We have tested the utility of these databases and proteomics for $H$. capsulatum by studying the response under ironlimiting conditions.

Iron is a major nutrient for growth of $H$. capsulatum both in vitro and in vivo [23-25]. Sequestration of iron by interferon gamma (IFN- $\gamma$ ) activated macrophages acts as a host defense mechanism against $H$. capsulatum [26]. The influence of iron availability on metabolic processes in $H$. capsulatum has only begun to be addressed. Recently a connection between iron availability and lipid metabolism was shown in H. capsulatum as iron-related alterations influenced the content of triacylglycerol and free fatty acids [27]. We have utilized 2D gel electrophoresis, statistical analysis, MS, and bioinformatics to identify $H$. capsulatum proteins sensitive to lowering iron availability. Using this platform, we discovered $42 \mathrm{H}$. capsulatum proteins whose abundance was altered when grown in the presence of iron scavenger apo-transferrin. Proteins found to be sensitive to decreasing iron levels suggest a requirement for $H$. capsulatum to mediate specific metabolic functions in order to cope with changes in the environment the organism most likely encounters in the host.

\section{Results and Discussion Proteomic platform development}

In order to set-up a platform for analyzing the H. capsulatum proteome, the optimal conditions for protein extraction from $H$. capsulatum yeast had to be determined. Several commercial lysis buffers were tested in our laboratory before selecting a buffer which provided the highest protein yield. The lysis buffer which yielded the highest protein yield was composed of $9 \mathrm{M}$ urea, $2 \%$ CHAPS, $1 \%$ DTT, and $10 \mathrm{mM}$ protease inhibitor. Figure 1 represents the 2D gel profile of proteins from H. capsulatum grown in liquid culture for 3 days and lysed using the aforementioned buffer. We consistently detected $\sim 1500$ protein spots.

We searched matrix assisted laser desorption/ionization time-of-flight (MALDI-TOF) mass spectrometer (MS) and nanoflow liquid chromatography (LC)-MS/MS data obtained from 2D in-gel digests of protein spots labeled in figure 1 against all the MASCOT searchable publicly available eukaryotic databases. Protein spots were selected based on intensity in order to test the quality of the different gene/protein databases to generate the most protein identifications. Following download and MASCOT modifications we searched the G186 database available at the Broad Institutes Fungal Genome Initiative. http:// www.broad.mit.edu/annotation/fgi/. Searching the public available databases and Broad yielded identifications for 34 out of 49 individual protein in-gel digests. In order to increase our protein identifications, a gene/protein database specific for the G217B H. capsulatum strain and compatible with MS search engines was constructed using a combination of different gene finding programs.

Database 1, consisting of 9348 sequences, was constructed using Fgenesh and parameters setup by Softberry http://www.softberry.com/berry.phtml. Fgenesh finds genes based on intrinsic characteristics of coding sequences such as codon usage and consensus splice sites [28]. Database 2 was assembled using the publicly available EST libraries of both mycelial and yeast phases, and assembled into full gene sequences with the aid of the CAP3 genome assembly program [29] yielding a database containing 6,233 gene sequences. Database 3 was originally assembled by Washington University St. Louis Genome Sequencing Center for microarray analysis using a combination of different gene finding programs which include Fgenesh, EAnnot, GeneWise, and SNAP [28,3032]. Database 3 contains a total of 14,506 predicted gene sequences.

MS data acquired from in-gel digests of proteins excised from the gel in figure 1 were searched against the 3 inhouse strain specific databases leading to the identification of all in-gel digests searched (table 1). Searching the 


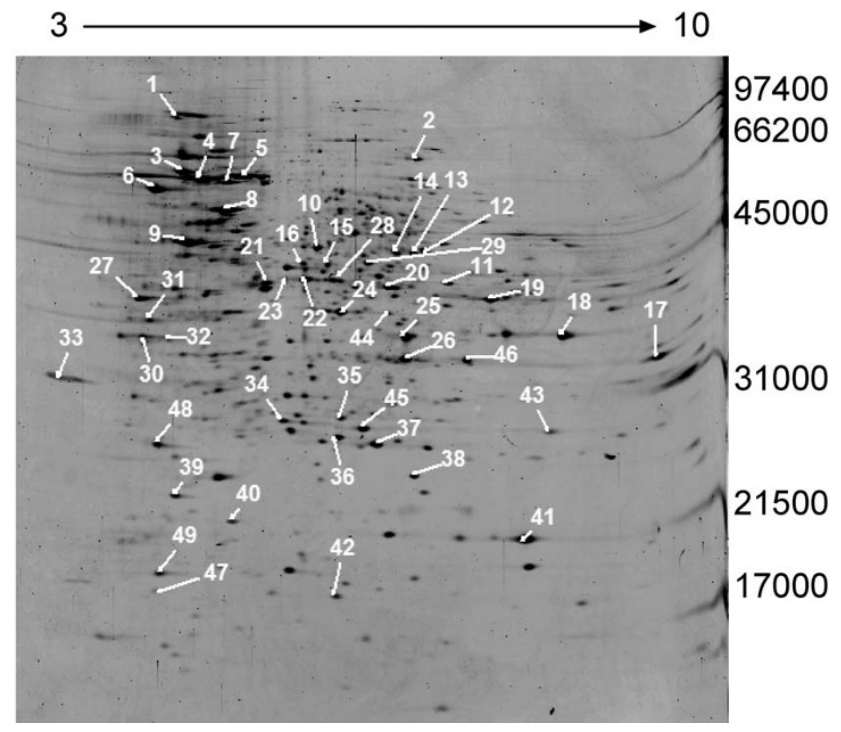

Figure I

2D-gel analysis of proteins from $\boldsymbol{H}$. capsulatum following 3-day growth. Identified spots are numbered and listed in table I. The gel was loaded with $50 \mu \mathrm{g}$ of total protein and stained with SYPRO Ruby fluorescent dye. The $\mathrm{pH}$ gradient is labeled on the top of the gel and molecular weight markers in Daltons are labeled on the right.

data against the publicly available eukaryotic databases and Broad sequences led to the identification of 34 proteins. Fifteen of these proteins would not have been identifiable without the strain specific databases. These fifteen proteins are marked by an * in table 1 . This illustrates the importance of having gene/protein sequence databases that are organism and strain-specific when conducting proteomic analyses.

The protein identifications (BLAST IDs) listed in table 1 are the best homology and functional matches following a BLAST search of the MS matched protein sequence in our custom databases against the NCBInr sequence database. If a protein sequence matched with a hypothetical sequence in the BLAST search, the next best protein BLAST sequence match with annotated functionality was listed. Forty percent of proteins detected are involved in energy or metabolism; 30\% belonged to the cell fate and rescue functional cluster. The most intensely SYPRO stained protein bands were heat shock proteins (HSP)s. In addition, MS data from spots 32 and 44 (Figure 1) matched two protein sequences in the Broad 186 strain databases only, neither of which had homology to any other protein sequence following BLAST searching.

Our mass fingerprinting (MFP) analysis was validated using a more sensitive and structurally informative tech- nique, LC-MS/MS analysis. We analyzed 3 digested proteins (Figure 1 spots; 6, 8, and 41) by MFP and LC-MS/MS (table 1) and all 3 matched with their respective protein using both MFP and LC-MS/MS. This included peptide sequence information for 14 fragments from spot 6 , six fragments from spot 8 , and 3 from spot 41 .

Databases were further validated using MS data acquired from in-gel digestion of HSP 60. MS data from in-gel tryptic digested HSP 60 matched exceptionally well with both public and in-house constructed databases. We matched $18 \mathrm{MS}$ generated molecular weights with 18 amino acid sequences to our in-house constructed databases for HSP 60 . Using the same MS data to search the publicly available fungal databases using MASCOT, we matched 13 peptides. This also shows the specificity of our databases for $H$. capsulatum, in that we were able to identify 5 additional peptides unique to $H$. capsulatum G217B, HSP 60 (data not shown).

\section{Iron depletion and 2D gel analysis}

Because iron utilization is crucial for successful $H$. capsulatum infection and limiting iron to the organism is believed to be a strategy used by the host, we analyzed $H$. capsulatum's protein response to decreases in iron availability. $H$. capsulatum requires iron for survival inside the host as chelation of iron inhibits fungal growth within mouse and human macrophages $[23,26]$. In mammalian hosts iron is bound to transferrin and lactoferrin or stored in ferritin. It has been proposed that $H$. capsulatum may acquire iron from transferrin by modulating $\mathrm{pH}$ [23] or by secreting siderophores [33]. Transcripts of genes coding for siderephore biosynthesis are upregulated under low iron conditions, and one gene, SID1, is involved in host colonization [34]. Another iron acquisition strategy is through the secretion of ferric reducing compounds $[25,35]$. Recently it has been shown that as H. capsulatum has a preference for ferrous iron [27], and a possible mechanism for $H$. capsulatum iron acquisition is through the ferric reductant activity of a $\gamma$-glutamyltransferase [36].

To create an environment more closely resembling that of the mammalian host, we used apo-transferrin to reduce the concentration of free iron in the medium in which $H$. capsulatum was grown by $90 \%$. Following $48 \mathrm{hr}$ growth in culture $H$. capsulatum was switched to a media containing $5 \mu \mathrm{M}$ apo-transferrin for $24 \mathrm{hr}$ and $48 \mathrm{hr}$. Following lysis of cells, 2D gel analysis was performed as shown in figure 2. The 2D gels were analyzed using SameSpots software developed by Nonlinear Dynamics. SameSpots detected and matched 3381 and 3968 protein spots for 24 and 48 groups respectively. A total of 146 and 154 spots were selected as significantly altered in abundance following $24 \mathrm{hr}$ and $48 \mathrm{hr}$ groups respectively. After manual 
Table I: List of proteins identified from the 2D gel shown in figure I following in-gel tryptic digestion, MALDI-MS analysis, and database searching.

\begin{tabular}{|c|c|c|c|c|c|}
\hline Spot \# & BLAST ID & $\begin{array}{l}\text { \# Peptides Matched/ } \\
\text { \#Searched }\end{array}$ & $\%$ Protein Coverage & Accession \# & MASCOT Score $(p<.05)$ \\
\hline Spot I* & $\begin{array}{l}\text { predicted protein [Ajellomyces } \\
\text { capsulatus NAm I]. }\end{array}$ & $8 / 17$ & $12 \%$ & XP_00I538505 & 71 \\
\hline Spot 2 & $\begin{array}{l}\text { aconitate hydratase, } \\
\text { mitochondrial precursor } \\
\text { [Ajellomyces capsulatus NAm I]. }\end{array}$ & $13 / 29$ & $14 \%$ & XP_00I539799 & 107 \\
\hline Spot 3 & $\begin{array}{l}\text { heat shock } 70 \mathrm{kDa} \text { protein } \mathrm{C} \\
\text { precursor [Ajellomyces } \\
\text { capsulatus NAm I]. }\end{array}$ & $12 / 17$ & $21 \%$ & XP_00I538200 & 150 \\
\hline Spot 4 & $\begin{array}{l}\text { heat shock protein } 70 \\
\text { [Paracoccidioides brasiliensis]. }\end{array}$ & $12 / 16$ & $17 \%$ & AAK6677I & 162 \\
\hline Spot $5(\mathrm{~A} \mid 0)$ & $\begin{array}{l}70 \mathrm{kDa} \text { heat shock protein } \\
\text { [Paracoccidioides brasiliensis]. }\end{array}$ & $12 / 26$ & $20 \%$ & AAP05987 & 125 \\
\hline Spot 6* & $\begin{array}{l}\text { protein disulfide-isomerase } \\
\text { precursor [Ajellomyces } \\
\text { capsulatus NAml]. }\end{array}$ & $6 / 9$ & $12 \%$ & XP_00I54I532 & 77 \\
\hline Spot 7 & $\begin{array}{l}\text { heat shock } 70 \mathrm{kDa} \text { protein } \\
\text { [Ajellomyces capsulatus NAm I]. }\end{array}$ & $7 / 10$ & $14 \%$ & XP_00I543760 & 90 \\
\hline Spot 8 & $\begin{array}{l}\text { heat shock protein } 60 \text {, } \\
\text { mitochondrial precursor } \\
\text { [Ajellomyces capsulatus } \mathrm{NAm} \mathrm{I} \text {. }\end{array}$ & $18 / 26$ & $34 \%$ & XP_00I539356 & 242 \\
\hline Spot 9 & $\begin{array}{l}\text { ATP synthase beta chain, } \\
\text { mitochondrial precursor } \\
\text { [Ajellomyces capsulatus NAm I]. }\end{array}$ & $13 / 24$ & $37 \%$ & XP_00I539339 & 159 \\
\hline Spot 10 (A2I) & $\begin{array}{l}\text { enolase [Paracoccidioides } \\
\text { brasiliensis]. }\end{array}$ & $|3 / 2|$ & $37 \%$ & ABQ45367 & 172 \\
\hline Spot II & $\begin{array}{l}\text { ubiquinol-cytochrome C } \\
\text { reductase complex core protein } \\
\text { 2, putative [Aspergillus fumigatus } \\
\text { Af293]. }\end{array}$ & $9 / 22$ & $25 \%$ & XP_00I53939I & 103 \\
\hline Spot 12 & $\begin{array}{l}\text { dihydrolipoamide } \\
\text { dehydrogenase [Ajellomyces } \\
\text { capsulatus NAmI]. }\end{array}$ & $8 / 11$ & $17 \%$ & XP_747922 & 119 \\
\hline Spot 13* & $\begin{array}{l}\text { fumarate hydratase class II } \\
\text { [Aspergillus terreus NIH2624]. }\end{array}$ & $8 / 20$ & $16 \%$ & XP_00I20989I & 91 \\
\hline Spot $14^{*}(\mathrm{~A} 29)$ & $\begin{array}{l}\text { saccharopine dehydrogenase } \\
\text { [Ajellomyces capsulatus NAm I]. }\end{array}$ & $6 / 16$ & $14 \%$ & XP_00I544528 & 64 \\
\hline Spot 15 & $\begin{array}{l}\text { elongation factor Tu, } \\
\text { mitochondrial precursor } \\
\text { [Aspergillus terreus NIH2624]. }\end{array}$ & $|2 / 2|$ & $38 \%$ & XP_00I210502 & 170 \\
\hline Spot 16 & $\begin{array}{l}\text { Pyruvate dehydrogenase EI } \\
\text { component alpha subunit, } \\
\text { mitochondrial precursor } \\
\text { [Ajellomyces capsulatus } \mathrm{NAmI}] \text {. }\end{array}$ & $9 / 18$ & $21 \%$ & XP_00I5443I3 & 106 \\
\hline Spot 17 (A38) & $\begin{array}{l}\text { malate dehydrogenase } \\
\text { [Ajellomyces capsulatus NAmI]. }\end{array}$ & $7 / 17$ & $21 \%$ & XP_00I54I87I & 86 \\
\hline Spot 18 & $\begin{array}{l}\text { glyceraldehyde-3-phosphate } \\
\text { dehydrogenase [Ajellomyces } \\
\text { capsulatus]. }\end{array}$ & $8 / 16$ & $35 \%$ & AAG33368 & 112 \\
\hline Spot 19 & $\begin{array}{l}\text { ketol-acid reductoisomerase, } \\
\text { mitochondrial precursor } \\
\text { [Ajellomyces capsulatus NAm I]. }\end{array}$ & $20 / 37$ & $46 \%$ & XP_00I536226 & 258 \\
\hline Spot 20 & $\begin{array}{l}\text { mannitol-I-phosphate } \\
\text { dehydrogenase } \\
\text { [Paracoccidioides brasiliensis]. }\end{array}$ & $16 / 22$ & $44 \%$ & AAO47089 & 234 \\
\hline Spot 21 & $\begin{array}{l}\text { conserved hypothetical protein } \\
\text { [Ajellomyces capsulatus NAm I]. }\end{array}$ & $9 / 18$ & $25 \%$ & XP_00I544536 & 118 \\
\hline Spot 22 & $\begin{array}{l}\text { peptidyl-prolyl cis-trans } \\
\text { isomerase [Ajellomyces } \\
\text { capsulatus } \mathrm{NAmI} \text { ]. }\end{array}$ & $14 / 30$ & $35 \%$ & XP_00I536169 & 170 \\
\hline Spot 23 & $\begin{array}{l}\text { peptidyl-prolyl cis-trans } \\
\text { isomerase [Aspergillus fumigatus } \\
\text { Af293]. }\end{array}$ & $|4 / 3|$ & $27 \%$ & XP_001536169 & 100 \\
\hline Spot $24^{*}$ & $\begin{array}{l}\text { fructose I,6-biphosphate } \\
\text { aldolase I [Paracoccidioides } \\
\text { brasiliensis]. }\end{array}$ & $4 / 7$ & $8 \%$ & AAL345I9 & 62 \\
\hline Spot $25^{*}$ & $\begin{array}{l}\text { RACKI-like protein } \\
\text { [Paracoccidioides brasiliensis]. }\end{array}$ & $6 / 16$ & $17 \%$ & ABA33785 & 76 \\
\hline
\end{tabular}


Table I: List of proteins identified from the 2D gel shown in figure I following in-gel tryptic digestion, MALDI-MS analysis, and database searching. (Continued)

\begin{tabular}{|c|c|c|c|c|c|}
\hline Spot 26* & $\begin{array}{l}\text { cytochrome c peroxidase Ccpl } \\
\text { [Aspergillus fumigatus Af293]. }\end{array}$ & $9 / 28$ & $25 \%$ & XP_751914 & 102 \\
\hline Spot $27^{*}$ & $\begin{array}{l}\text { protein disulfide-isomerase } \\
\text { precursor [Ajellomyces } \\
\text { capsulatus NAm I]. }\end{array}$ & $5 / 12$ & $7 \%$ & XP_00I54I532 & 68 \\
\hline Spot 28 & $\begin{array}{l}\text { gene encoding Histoplasma } \\
\text { capsulatum predicted protein } \\
(248 \mid \mathrm{nt})\end{array}$ & $5 / 12$ & $5 \%$ & HCAG_0II43 & 65 \\
\hline Spot $29 *$ & $\begin{array}{l}\text { mRNA binding post- } \\
\text { transcriptional regulator (Csxl) } \\
\text { [Aspergillus fumigatus Af293]. }\end{array}$ & $5 / 13$ & $16 \%$ & XP_746709 & 66 \\
\hline Spot 30* & $\begin{array}{l}\text { gene encoding Histoplasma } \\
\text { capsulatum predicted protein } \\
(2328 \mathrm{nt})\end{array}$ & $5 / 16$ & $10 \%$ & HCAG_06550 & 68 \\
\hline Spot $31 *$ & $\begin{array}{l}\text { hypothetical protein } \\
\text { RUMOBE_030I5 } \\
\text { [Ruminococcus obeum ATCC } \\
\text { 29174] }\end{array}$ & $5 / 9$ & $9 \%$ & ZP_01965283 & 74 \\
\hline Spot 32 & HCAG_04492 & $4 / 7$ & $7 \%$ & - & 60 \\
\hline Spot 33 & $\begin{array}{l}\text { Hsp90 binding co-chaperone } \\
\text { (SbaI) [Aspergillus fumigatus } \\
\text { Af293]. }\end{array}$ & $6 / 18$ & $19 \%$ & XP_753264 & 72 \\
\hline Spot 34 & $\begin{array}{l}\text { thiol-specific antioxidant } \\
\text { [Ajellomyces capsulatus NAm I]. }\end{array}$ & $10 / 21$ & $38 \%$ & XP_00I538605 & 142 \\
\hline Spot $35^{*}$ & $\begin{array}{l}\text { triosephosphate isomerase } \\
\text { [Aspergillus clavatus NRRL I]. }\end{array}$ & $7 / 19$ & $33 \%$ & XP_00I 274623 & 103 \\
\hline Spot 36 & $\begin{array}{l}30 \mathrm{kDa} \text { heat shock protein } \\
\text { [Ajellomyces capsulatus NAm I]. }\end{array}$ & $10 / 28$ & $31 \%$ & XP_00I54027I & 125 \\
\hline Spot 37 & $\begin{array}{l}\text { superoxide dismutase, } \\
\text { mitochondrial precursor } \\
\text { [Ajellomyces capsulatus NAm I]. }\end{array}$ & $5 / 16$ & $21 \%$ & XP_00I54I35I & 78 \\
\hline Spot 38 & $\begin{array}{l}\text { ATP synthase D chain, } \\
\text { mitochondrial [Ajellomyces } \\
\text { capsulatus NAm I]. }\end{array}$ & $7 / 19$ & $31 \%$ & XP_00I53963I & 102 \\
\hline Spot 39 & $\begin{array}{l}\text { tropomyosin, putative } \\
\text { [Neosartorya fischeri NRRL } \\
\text { 18I]. }\end{array}$ & $6 / 12$ & $27 \%$ & XP_00I26I343 & 98 \\
\hline Spot $40^{*}$ & $\begin{array}{l}\text { protein of unknown function } \\
\text { DUFI8I [Methylobacterium } \\
\text { radiotolerans JCM 283I]. }\end{array}$ & $5 / 9$ & $14 \%$ & YP_00I756253 & 76 \\
\hline Spot 4I & $\begin{array}{l}\text { peptidyl-prolyl cis-trans } \\
\text { isomerase (cyclophilin) } \\
\text { [Ajellomyces capsulatus NAmI]. }\end{array}$ & $7 / 24$ & $26 \%$ & XP_00I540645 & 91 \\
\hline Spot 42 & $\begin{array}{l}\text { putative cytochrome c oxidase } \\
\text { subunit Vla [Paracoccidioides } \\
\text { brasiliensis]. }\end{array}$ & $5 / 14$ & $13 \%$ & AAT77।46 & 76 \\
\hline Spot 43 & $\begin{array}{l}\text { woronin body major protein } \\
\text { [Ajellomyces capsulatus NAm I]. }\end{array}$ & $4 / 8$ & $15 \%$ & XP_00I543637 & 63 \\
\hline Spot 44 (A5) & $\begin{array}{l}\text { HCAG_04I47 } \\
\text { (Hypothetical Protein) }\end{array}$ & $5 / 10$ & $9 \%$ & - & 66 \\
\hline Spot $45^{*}(A 42)$ & $\begin{array}{l}\text { asparaginyl-tRNA synthetase } \\
\text { [Flavobacterium sp. MED2I7]. }\end{array}$ & $6 / 18$ & $16 \%$ & ZP_01059347 & 65 \\
\hline Spot 46 & $\begin{array}{l}\text { ATPase associated with various } \\
\text { cellular activities AAA_3 } \\
\text { [Shewanella woodyi ATCC } \\
51908 \text { ] }\end{array}$ & $6 / 16$ & $11 \%$ & YP_00176I394 & 67 \\
\hline Spot $47^{*}$ & $\begin{array}{l}\text { cystathionine beta-lyase } \\
\text { [Rhizobium etli CFN 42]. }\end{array}$ & $6 / 14$ & $13 \%$ & YP_4694II2 & 62 \\
\hline Spot 48 & $\begin{array}{l}\text { heat shock protein } 70 \\
\text { [Paracoccidioides brasiliensis]. }\end{array}$ & $7 / 11$ & $12 \%$ & AAK6677I & 120 \\
\hline Spot 49 & $\begin{array}{l}\text { hypothetical protein NCU0759I } \\
\text { [Neurospora crassa OR74A]. }\end{array}$ & $4 / 7$ & $7 \%$ & XP_96297I & 64 \\
\hline
\end{tabular}

Numbers in parentheses correspond to protein ID in figure 2. 
inspection and removal of streaks, areas around streaks, dirt, etc. approximately 1500 proteins spots were accepted as valid protein spots. Of these 1500 spots, a total of 42 proteins $(\sim 3.0 \%)$ were accepted as significantly altered (p $<0.05$ ) in abundance following $H$. capsulatum growth in the presence of apo-transferrin for $24 \mathrm{hr}$ and $48 \mathrm{hr}$.

Proteins with statistically significant spot volume changes are circled in white, numbered in Figures $2 \mathrm{~B}$ and 2D. The 42 proteins circled in white represent fold changes in a range of $1.3-2.8$, and p values $<.05$. Spot volume ratios of all proteins detected and matched using SameSpots were subjected to a global one-way ANOVA statistical test. ANOVA was used to define a subset of individual proteins that exhibited statistically significant abundance changes (normalized volume ratios) as one-way ANOVA analysis is designed to test differences between means in multiple sample groups. Twenty four and $48 \mathrm{hr}$ groups were analyzed separately.

\section{Proteins sensitive to changes in iron availability}

Seven $H$. capsulatum proteins were more abundant while 35 proteins were less abundant following growth in ironpoor (apo-transferrin) medium. A list of these proteins and their corresponding fold changes and p values can be found in the additional file 1. Protein spots identified by MS are labeled A for apo-transferrin in table 1. Protein sequences with homology to enolase (spot A21 Figure 2D), malate dehydrogenase (spot A38 Figure 2D), saccharopine dehydrogenase (spot A29 Figure 2D), HSP 70 (spot A10 Figure 2D), asparaginyl-tRNA synthetase (spot A42 Figure 2D), and an uncharacterized protein with an amino acid sequence unique to $H$. capsulatum (spot A5 Figure $2 \mathrm{~B}$ ) were among the 35 proteins less abundant following $H$. capsulatum growth in apo-transferrin medium. Fold changes and $\mathrm{p}$ values calculated by the SameSpots software were as follows; enolase ( -1.4 fold change/p value $=.0193)$, malate dehydrogenase $(-1.4 / .02920)$, saccharopine dehydrogenase (-1.5/.0377), HSP $70(-1.4 /$ $.0227)$, asparaginyl-tRNA synthetase (-1.4/.0422), and an uncharacterized protein unique to $H$. capsulatum $(-1.4 /$ $.0293)$. This protein was less abundant during the first 24 $\mathrm{hr}$ incubation with apo-transferrin and returns to baseline another $24 \mathrm{hr}$ later (Figure 2D, A5).

Magnified regions from the 2D gels for proteins with sequence homology to HSP 70, saccharopine dehydrogenase, cyclophilin and GAPDH are shown in Figure 3. Figure 3A depicts saccharopine dehydrogenase, labeled A29 in Figure 2D. The calculated fold change and $p$ value was -1.5 and 0.0377 respectively. HSP 70, spot A10 in Figure $2 \mathrm{D}$, was also statistically less abundant in iron replete medium and the fold change was $-1.4(\mathrm{p}=0.0227)$. Peptidyl-prolyl cis-trans isomerase (cyclophilin) and GAPDH were not statistically different in the presence or absence of apo-transferrin.

Enolase and malate dehydrogenase are involved in cellular respiration steps of the tricarboylic acid (TCA) or Krebs cycle and the last step of glycolysis before entering the TCA cycle respectively. Enolase, malate dehydrogenase, and other transcripts involved in the TCA cycle were also less abundant following microarray analysis of C. albicans, C. neoformans, and Escherichia coli under iron depletion conditions [37-39]. Fold changes of 1.56 and 1.87 for enolase and malate dehydrogenase transcripts respectively detected by microarray analysis of $C$. neoformans [38] under reduced iron availability was similar to those observed in our analysis. Isolating H. capasulatum following ingestion from IFN- $\gamma$ activated macrophages we found that malate dehydrogenase was also significantly altered in abundance (fold change of 5.6, $\mathrm{p}=0.0153$ ) compared to the organism grown under the same conditions in culture (additional file 2). When faced with limitation of iron, yeasts will not only increase their iron uptake and their mobilization of stored iron, but also adjust their metabolism to more efficiently use the iron that is available [40]. The availability of iron in $H$. capsulatum has also been shown to affect the amount of triacylglycerols implicating a potential role of iron in lipid metabolism[27].

In addition to proteins involved in cellular respiration, we observed HSP 70 less abundant in H. capsulatum when grown in an iron deficient environment. HSP 70 is involved in the biogenesis of iron cluster proteins. Again our results are consistent with what was observed following microarray analysis of transcripts which code these proteins in C. ablicans following iron depletion [37]. HSPs may chaperone $\mathrm{Fe}-\mathrm{S}$ proteins or may be involved in the transfer or iron centres to recipient proteins thus their productivity may decrease when iron levels are lowered.

We also discovered proteins with sequence homology to saccharopine dehydrogenase and asparaginyl-tRNA synthetase whose abundance was decreased when $H$. capsulatum's growth medium iron concentrations were reduced. Saccharopine dehydrogenase is an enzyme involved in lysine metabolism while tRNA synthetase enzyme is required for protein synthesis by catalyzing the specific attachment of asparagine to its cognate tRNA. Out of $\sim 1500$ proteins profiled in our model we observed $\sim 2.0 \%$ reduction in protein abundance when $H$. capsulatum was incubated with apo-transferrin for $48 \mathrm{hr}$. Taken together these data could suggest a global reduction in protein synthesis by $H$. capsulatum when confronted with reductions in iron availability. To the authors knowledge neither asparaginyl-tRNA synthetase or saccharopine dehydrogenase have been connected to any other organism's response to lowering iron levels. 

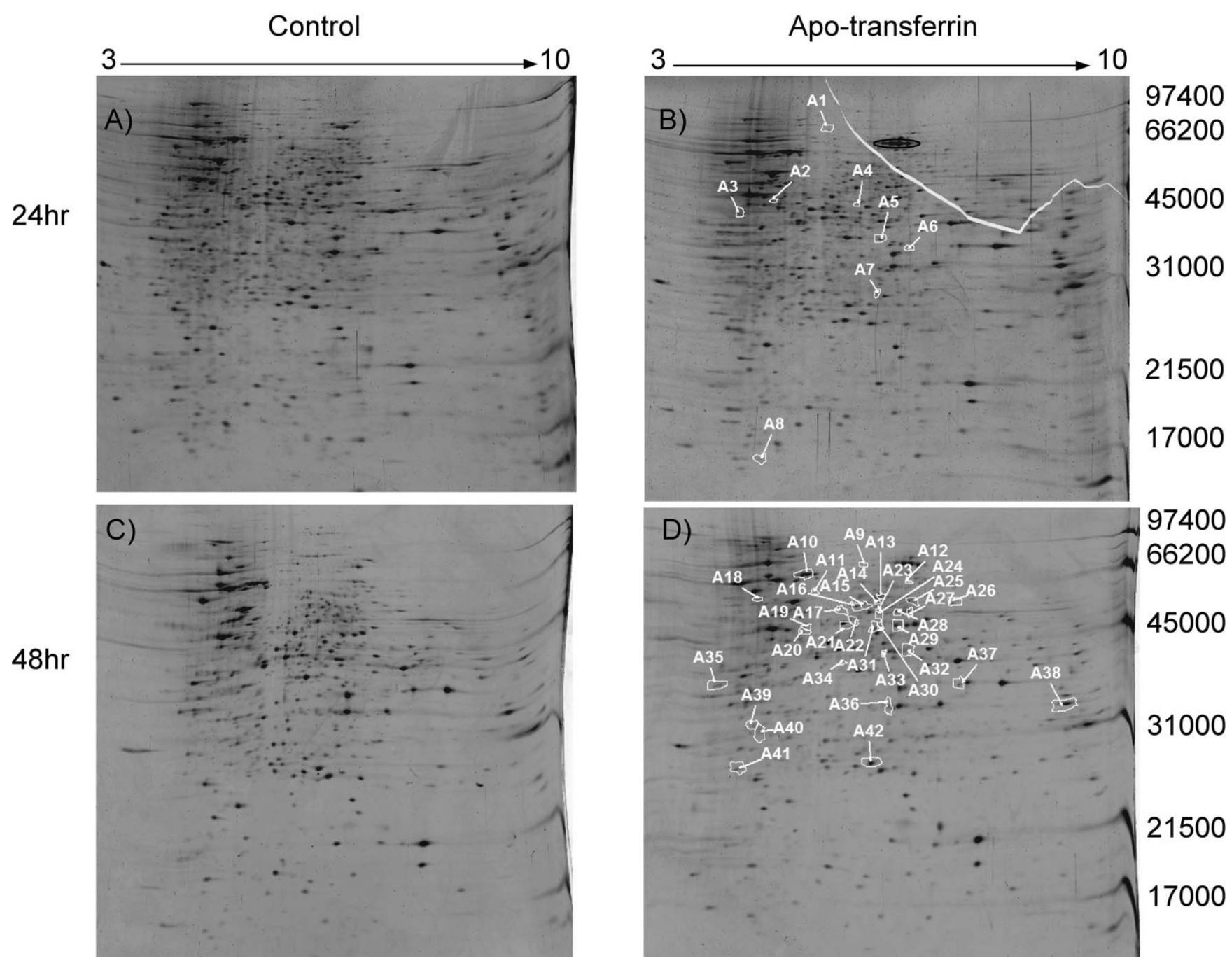

Figure 2

2D-gel analysis of Histoplasma capsulatum proteins following A) 3-day growth in liquid culture. B) 2-day growth in liquid culture followed by $24 \mathrm{hr}$ with growth media containing $5 \mu \mathrm{M}$ apo-transferrin. Protein spot circled in black is apo-transferrin C) 4-day growth in liquid culture D) 2-day growth followed by $48 \mathrm{hr}$ with growth media containing $5 \mu \mathrm{M}$ apo-transferrin. Proteins selected as statistically different in their protein abundance between control and apo-transferrin treated are circled and numbered in white by the SameSpots sofware. The $\mathrm{pH}$ gradient is labeled on the top of the gel and molecular weight markers are labeled in Daltons on the right. Gels were loaded with $50 \mu \mathrm{g}$ of total protein and stained with SYPRO Ruby fluorescent dye.

\section{Western blot analysis}

Western blot analysis was performed using antibodies specific to a protein that was not affected by iron levels as defined by 2D gel analysis, cyclophilin (Figure 4A), and a protein less abundant when iron levels were lowered, HSP 70 (Figure 4B). Statistical analysis of the calculated spot density values for HSP 70 biological replicates yielded a statistically significant difference, $\mathrm{p}$ value of 034 (Figure 4C). Differences between density values for cyclophilin were not significant.

\section{Methods \\ Reagents}

Trifluoroacetic acid (TFA) was obtained from Applied Biosystems (Warrington, WA). High performance liquid chromatography (HPLC)-grade acetonitrile, methanol, acetic acid, HPLC-grade water, ammonium bicarbonate, dithiothreitol (DTT), acrylamide, iodoacetamide, urea, and 3-[3-(Cholamidopropyl) dimethylammonio]-1proanesulfonate (CHAPS) were obtained from Fisher (Fair Lawn, New Jersey). Carrier ampholytes (pH 3-10) 


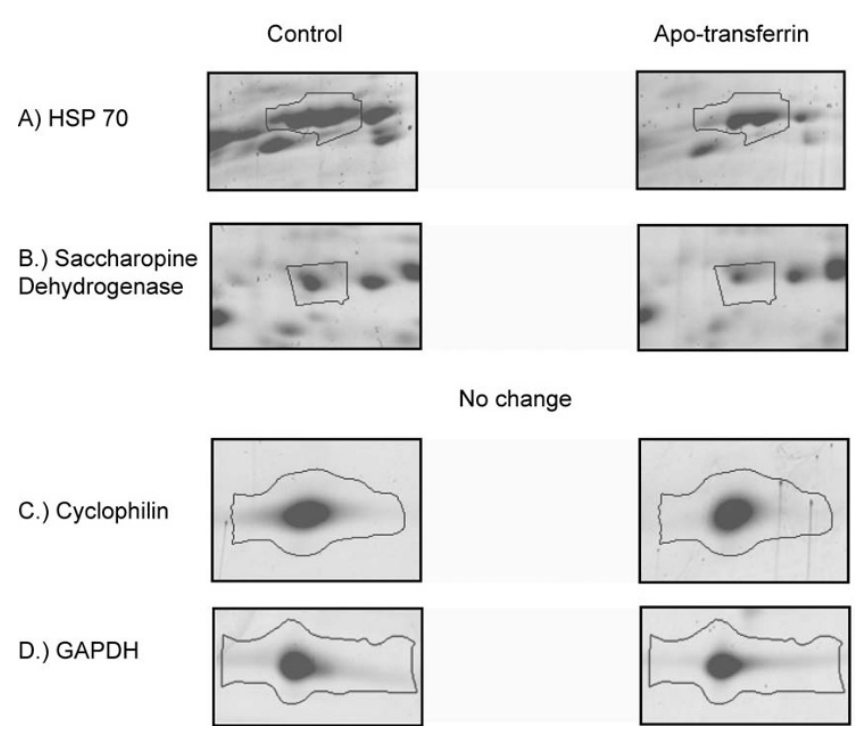

Figure 3

Magnified regions of the 2D gels shown in figures 2c and 2d. A.) Protein band corresponds with HSP70 (AI0) B.) Protein band corresponds to saccharopine dehydrogenase (A29) C.) Protein bands cyclophilin and GAPDH did not change significantly in their abundance following apo-transferrin treatment. Protein band outlines were created by the SameSpots software.

and formic acid were purchased from Fluka Chemicals (Milwaukee, WI). SYPRO Ruby fluorescent dye was obtained from Invitrogen Molecular Probes (Carlsbad, CA). $\alpha$-Cyano-4-hydroxycinnamic acid, bathophenathrolinedisulfonic acid (BPS), and protease inhibitor cocktail for fungal and yeast cells (P8215) was purchased from Sigma Aldrich (St. Louis, MO). Sequence grade trypsin was obtained from Promega (San Luis Obispo, CA). 4chloro-1-naphthol HRP development was obtained from BioRad (Hercules, CA). HRP conjugate secondary antibodies were purchased from Pierce (Rockford, IL). HSP70 mouse monoclonal antibody was purchased from Sressgen (Victoria, BC Canada). Cyclophilin mouse monoclonal antibody was a gift from Francisco Gomez (University of Cincinnati, Infectious Disease).

\section{Sample preparation}

H. capsulatum yeast (strain G217B) were prepared by inoculating $50 \mathrm{ml}$ of medium, previously described [41], with $3 \times 10^{6}$ cells $/ \mathrm{ml}$ from $3-5$ days old slants to give a concentration of $1.5 \times 10^{8}$ cells $/ \mathrm{ml}$ after 3 days. H. capsulatum yeasts were grown in medium set at $\mathrm{pH} 7.5$ for $48 \mathrm{hr}$ and switched to medium containing $5 \mu \mathrm{M}$ apo-transferrin or medium free of apo-transferrin. One ml aliquots $\left(\sim 10^{8}\right.$ cells) were removed following $24 \mathrm{hr}$ and $48 \mathrm{hr}$ incubation with $5 \mu \mathrm{M}$ apo-transferrin and medium free of apo-transferrin. Samples were then centrifuged at $1500 \times \mathrm{g}$ for 10 min. The supernatant was removed and $250 \mu \mathrm{l}$ of lysis buffer (9 M urea, 2\% CHAPS, 1\% DTT, and $10 \mathrm{mM}$ fungal and yeast cell protease inhibitor) was added. Cells were disrupted with a Min-Beadbeater (BioSpec Products, Bartlesville, OK) using an equal volume of glass beads for 30 sec and placed on ice for $30 \mathrm{sec}$. This was repeated 3 times. Following cell disruption, $250 \mu \mathrm{l}$ of lysis buffer was added and samples were allowed to cool on ice for $10 \mathrm{~min}$. Samples were then centrifuged at $15,000 \times \mathrm{g}$ for $30 \mathrm{~min}$. An equal volume of water was added to each sample and further concentrated to $100 \mu \mathrm{l}$ using an Amicon Ultra Centrifugal Filter Device. The clear supernatant was removed and protein concentrations were determined using the Bradford method.

We confirmed that apotransferrin did reduce iron levels by measuring the amount of iron bound to transferrin using the iron chelator bathophenathrolinedisulfonic acid (BPS) as described previously $[42,43]$. One $\mathrm{ml}$ of media containing $5 \mu \mathrm{M}$ apo-transferrin was concentrated using Amicon Ultra Centrifugal Filter Device. To the concentrated transferrin $(100 \mu \mathrm{l})$, nitric acid was added to give a $3 \%$ concentration followed by the addition of 38 $\mathrm{mg} / \mathrm{ml}$ sodium ascorbate, $1.7 \mathrm{mg} / \mathrm{ml}$ BPS, and ammonium acetate (saturated ammonium acetate dilute 1/3) were added to the concentrated transferrin effectively denaturing the protein and reducing all iron to the ferrous form. After $5 \mathrm{~min}$ the absorbance was recorded at $535 \mathrm{~nm}$ for the concentrated retintate and flow through. Based on measuring the amount of iron bound to apo-transferrin the quantity of iron in the medium prior to addition of apotransferrin was $.0008 \mathrm{~g} / \mathrm{L}$ and following $24 \mathrm{hr}$ in $5 \mu \mathrm{M}$ apo-transferrin the concentration was reduced by $\sim 83 \%$. At $5 \mu \mathrm{M}$ apo-transferrin changes in the amount of iron bound to apo-transferrin in the presence or absence of $H$. capsulatum was not detected.

Mass spectrometry was also used to measure the reduction of iron levels. The inductively coupled plasma mass spectrometer (ICP-MS) based quantification method has been commonly used to determine accurate concentration of metals in complex matrices. Specific iron detection in our samples was performed with an ICP-MS 7500cx (Agilent Technologies, Tokyo, Japan) equipped with an octopole collision/reaction cell system. Two isotopes of iron, ${ }^{56} \mathrm{Fe}^{+}$ and ${ }^{57} \mathrm{Fe}^{+}$, were monitored using $\mathrm{He}$ as collision gas at 4.0 $\mathrm{ml} \mathrm{min}{ }^{-1}$ to reduce the ${ }^{40} \mathrm{Ar}^{16} \mathrm{O}^{+}$and ${ }^{40} \mathrm{Ar}^{16} \mathrm{O}^{1} \mathrm{H}^{+}$interferences. The RF power was $1450 \mathrm{~W}$ and carrier gas flow rate was $1.02 \mathrm{~L} \mathrm{~min}^{-1}$. Apo-transferrin medium was filtered through a $10 \mathrm{kD}$ membrane filter before analyzed by ICPMS. Total iron levels were lowered from $57.15 \mathrm{ppb}( \pm$ $.84)$, to $5.93( \pm 1.27) \mathrm{ppb}$ when $5 \mu \mathrm{M}$ of apo-transferrin was added to the medium, a reduction of $\sim 90 \%$ of the total iron. Standard deviations were calculated from 3 biological replicates. 


\section{D-gel electrophoresis and statistical analysis}

Fifty $\mu \mathrm{g}$ of protein were mixed with rehydration buffer $(9$ $M$ urea, 2\% CHAPS, 1\% dithiothreitol (DTT), and carrier ampholyte (pH 3-10) solution, $20 \mu \mathrm{l} / 1 \mathrm{ml}$ ). A total of $350 \mu \mathrm{l}$ of this rehydration solution was loaded onto $24 \mathrm{~cm}$ immobilized protein gradient (IPG) strips pH 3-10 (Amersham Biosciences, GE Healthcare, Piscataway, NJ) and incubated (rehydrated) for $12 \mathrm{hr}$. Isoelectric focusing (IEF) was performed with an IPGphor system (Amersham Biosciences) using a step gradient starting from $0-500 \mathrm{~V}$ for $1 \mathrm{hr}, 500-1000 \mathrm{~V} 1 \mathrm{hr}, 1000-8000 \mathrm{~V} 12.5 \mathrm{hr}$, and $8000 \mathrm{~V}$ for $2.5 \mathrm{hr}$. Following IEF, strips were stored at $70^{\circ} \mathrm{C}$.

Strips were then equilibrated for $30 \mathrm{~min}$ in $15 \mathrm{ml}$ of $6 \mathrm{M}$ urea, 20\% glycerol, .05 M Tris, 2\% SDS, $75 \mathrm{mg}$ DTT, and a few crystals of bromophenol blue. Strips were then loaded onto a $10 \%$ SDS PAGE gel. The second dimension was run at $200 \mathrm{~V}$ for $15 \mathrm{~min}$ followed by $300 \mathrm{~V}$ for $4-5 \mathrm{hr}$. Gels were next fixed for 15 minutes in 10\% methanol/7\% acetic acid. Gels were then stained overnight with SYPRO Ruby fluorescent dye and destained for 20 minutes in fixing solution. Gel images were produced using a GE Healthcare Typhoon scanner. Before image analysis, gels were washed with water for 5-10 min.

2D gel spot detection, matching, and spot volume, calculations were performed using SameSpots (Nonlinear Dynamics, Durham, NC) software on three biological replicates, six gels per 24 and $48 \mathrm{hr}$ apo-transferrin treatments and their respective controls. Spot volumes for all protein spot matches within each analysis were calculated and normalized to the total spot volume yielding a spot volume ratio. This ratio enabled the calculation of average abundance changes across all 3 replicates within each test group and the application of ANOVA statistical test. Individual spots were ranked by p-value from a one way global ANOVA analysis, with maximum fold change based on spot normalized volume. P values of $<0.05$ were considered statistically significant and reflect the probability that the observed change did not occur from random noise.

\section{H. capsulatum viability test}

To verify that the proteins found altered in our analysis did not result from the death of $H$. capsulatum, the organism was plated on solid medium following 24 and $48 \mathrm{hr}$ growth with apo-transferrin. One hundred yeast were plated from cultures growing with or without apo-transferrin for $48 \mathrm{~h}$. Eighty four colonies were counted on plates from $H$. capsulatum cultures containing apo-transferrin while 82 were counted from cultures free of apotransferrin. Thus any changes we might find would be a direct response from the stress we were applying, and not from $H$. capsulatum death.

\section{In-gel digestion}

Protein bands were excised and diced into small pieces ( 1 $\mathrm{mm}$ ) and placed into $0.65 \mathrm{~mL}$ siliconized tubes (PGC Scientific). Each gel piece was briefly incubated and washed with $100 \mu \mathrm{l}$ of water. Gel pieces were resuspended in $100 \mu \mathrm{l}$ of acetonitrile and placed in a speed vacuum until dry. Next, $30 \mu \mathrm{L}$ of $10 \mathrm{mM}$ DTT in $25 \mathrm{mM}$ ammonium bicarbonate was added to the dried gel pieces. Samples were vortexed and centrifuged briefly. The reaction was allowed to proceed at $56^{\circ} \mathrm{C}$ for $1 \mathrm{hr}$. The supernatant was removed and $30 \mu \mathrm{l}$ of $55 \mathrm{mM}$ iodoacetamide was added to the gel pieces. Samples were vortexed and centrifuged briefly. The reaction was allowed to proceed in the dark for $45 \mathrm{~min}$ at room temperature. Supernatant was removed and the gels were washed with $100 \mu \mathrm{l}$ of ammonium bicarbonate by vortexing for $10 \mathrm{~min}$. Supernatant was removed and gel pieces were dehydrated in $100 \mu \mathrm{L}$ of $25 \mathrm{mM}$ ammonium bicarbonate $/ 50 \% \mathrm{ACN}$, vortexed for $5 \mathrm{~min}$, and centrifuged. This step was repeated. Gel pieces were placed in a vacuum centrifuge until dry. Thirty microliters of a $12.5 \mathrm{ng} / \mathrm{ml}$ trypsin solution was added to the gel pieces and rehydrated on ice at $4{ }^{\circ} \mathrm{C}$ for $10 \mathrm{~min}$. Supernatant was removed, samples were centrifuged, and $25 \mu \mathrm{L}$ of $25 \mathrm{mM}$ of ammonium bicarbonate was added. Samples were centrifuged briefly and incubated at $37^{\circ} \mathrm{C}$ overnight. Following overnight digestion the solution was placed into a clean $0.65 \mathrm{~mL}$ siliconized tube. To the gel pieces, $50 \mu \mathrm{L}$ of $50 \%$ acetonitrile $/ 5 \%$ trifluoroacetic acid acid (TFA) was added. Samples were vortexed for $30 \mathrm{~min}$, sonicated for $5 \mathrm{~min}$, and the solution was combined with the first aqueous extraction. This was repeated and samples were then dried in a vacuum centrifuge.

\section{MALDI-TOF mass spectrometric analysis}

Dried peptide extracts were dissolved in $5 \mu \mathrm{L}$ of water. Next, $2.5 \mu \mathrm{L}$ of sample was mixed with $2.5 \mu \mathrm{L}$ of alphacyano-4-hydroxycinammic acid in 50\% acetonitrile/5\% TFA, $10 \mathrm{mg} / \mathrm{mL}$, and $1 \mu \mathrm{L}$ of sample was delivered to a gold plated matrix assisted laser desorption/ionization time-of-flight (MALDI-TOF) mass spectrometer (MS) sample plate. Mass spectra were collected on a VoyagerDE PRO (Applied Biosystems, Foster City, CA) MALDITOF MS. Each spectrum was an average of 200 laser shots. Trypsin autodigestion peaks (2211.11 and 842.51) were used to calibrate each spectrum.

Raw MALDI-TOF data were processed using manufacturer-supplied Data Explorer software, with the following settings: Baseline correction parameters; peak width 32, flexibility .5, and degree .1 Noise filter/smooth was selected with a correlation factor of .7. Each MALDI spectrum was manually inspected to create a peak list. To control for peaks generated from keratin and trypsin, a spot was cut from an area of the gel containing no protein, and prepared with each sample. Peaks which were in both ker- 
Con Apo

A) Cyclophilin

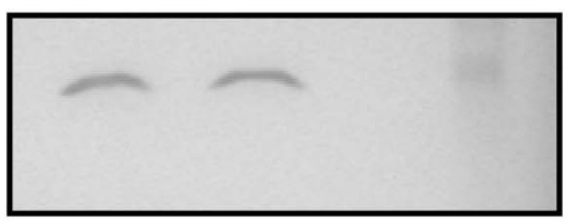

$18.3 \mathrm{kDa}$

Con Apo

B) HSP 70

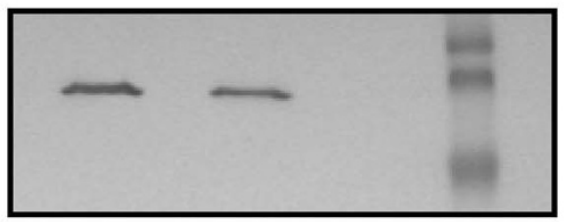

$73 \mathrm{kDa}$

$44 \mathrm{kDa}$

$33 \mathrm{kDa}$

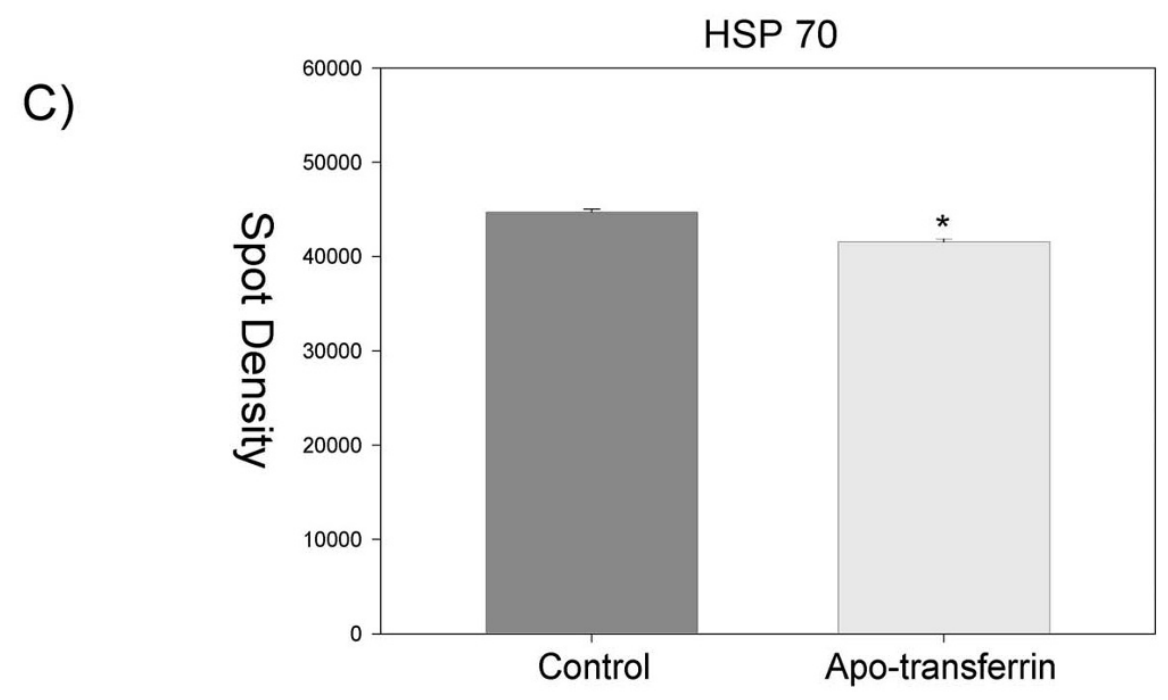

\section{Figure 4}

Western blot analysis of proteins extracted from $\mathrm{H}$. capsulatum grown with apo-tranferrin for 48 hr versus cultures free of apo-transferrin. A) using antibody against Cyclophilin (S4I, Figure I) which showed no statistically different changes in protein abundance from our 2D gel analysis. B) using antibody against HSP70 which was found more abundant following 2D gel analysis in the medium free of apo-transferrin compared to medium containing apo-transferrin. C) Graphical representation of spot density calculation from biological replicates probing for HSP 70, $\mathrm{p}$ value $=.034$. 
atin/trypsin control and sample spectra were excluded from peak lists.

\section{LC-MSIMS analysis}

For nanoflow liquid chromatography (LC)-MS/MS analysis, dried peptide extracts were dissolved in $5 \mu \mathrm{L}$ of $2 \%$ acetonitrile, $0.1 \%$ formic acid in water. Resuspended samples were loaded onto a Symmetry $5 \mu \mathrm{m}$ particle, $180 \mu \mathrm{m}$ $\times 20 \mathrm{~mm}$ C18 precolumn (Waters, Milford, MA), then washed 5 min with $1 \%$ acetonitrile in $0.1 \%$ formic acid at a flow rate of $20 \mu \mathrm{L} / \mathrm{min}$. After washing, peptides were eluted and passed through an Atlantis $3 \mu \mathrm{m}$ particle, 75 $\mu \mathrm{m} \times 100 \mathrm{~mm}$ C18 analytical column (Waters, Milford, MA) with a gradient of $1-80 \%$ Acetonitrile in $0.1 \%$ formic acid. The gradient was delivered over $120 \mathrm{~min}$ by a nanoACQUITY UPLC (Waters, Milford, MA) at a flow rate of $250 \mathrm{nl} / \mathrm{min}$, to a fused silica distal end-coated tip nanoelectrospray needle (New Objective, Woburn, MA). Data were collected on a Q-TOF Premiere mass spectrometer (Waters, Milford, MA) set for MS survey scans and automatic data-dependent MS/MS acquisitions, which were invoked after selected ions met preset parameters of minimum signal intensity of 10 counts per second, ion charge state $2+, 3+$, or $4+$, and appropriate retention time. Survey scans of $1 \mathrm{~s}$ were followed by collision induced dissociation (CID) of the three most intense ions for up to $6 \mathrm{~s}$ each, or until 10,000 total MS/MS ion counts per precursor peptide were attained.

Raw LC-MS/MS data were processed using manufacturersupplied ProteinLynxGlobalServer 2.2 software, with the following settings: Adaptive background subtraction of polynomial order 5 below a 35\% curve, two smooths with a window of three channels in Savitzky Golay mode, followed by fast deisotoping and centroid calculation of the top $80 \%$ of peaks based on a minimum peak width of 4 channels at half-height. On the basis of these parameters, pkl files incorporating parent ion mass and peak lists for each corresponding MS/MS spectrum were generated.

\section{Database searching}

Protein/genomic databases 1,2 and 3 were constructed beginning with the $H$. capsulatum G217B strain genome obtained from Washington University's Genome Sequencing Center website http:// www.genome.wustl.edu/home.cgi. Database 1 was constructed using only Fgenesh and parameters setup by Softberry http://www.softberry.com/berry.phtml. Database 2 was assembled using publicly available EST libraries, also retrieved from Washington University's Genome Sequencing Center website http:// www.genome.wustl.edu/home.cgi. EST's were generated from $H$. capsulatum cDNA under both mycelial and yeast phases, and assembled into full gene sequences with the aid of the contig assembly program (CAP) 3 genome assembly program [29]. Database 3 was assembled using a combination of the gene finding programs Fgenesh, EAnnot, GeneWise, and SNAP [28,30-32].

MALDI-TOF MS and LC-MS/MS data were used to search in-house databases 1-3 and publicly available fungal databases using MASCOT (version 2.1, Matrix Science, London, United Kingdom). A protein match from either of the 3 databases would count as a hit. Only protein matches deemed statistically significant $(\mathrm{p}<.05)$ by the MASCOT algorithm were accepted as protein sequence matches. For MALDI-TOF data, a 50 ppm mass accuracy threshold was set while a minimum precursor and fragment-ion mass accuracy of 1.2 and 0.8 Daltons was required for LC-MS/MS data. Up to 1 missed trypsin cleavage was allowed while fixed and variable carbamidomethyl were selected for separate searches. A decoy database was constructed by scrambling our in-house database sequences, and used to estimate false positive protein ID rates. Searching MS data against the decoy database did not result in any significant MASCOT scores. In order to annotate the protein sequence matches obtained from searching databases 1-3, each sequence was BLAST searched against the NCBInr sequence database.

\section{Western blot analysis}

H. capsulatum proteins prepared for 2D gel analysis were also probed using different antibodies specific for either cyclophilin or HSP 70. Ten micrograms of protein was mixed with $1 \times$ sample buffer $(5 \times ; 200 \mathrm{mM}$ Tris-HCl, $\mathrm{pH}$ $6.8,50 \%$ glycerol, $5 \%$ SDS, .5\% bromphenol blue, and $5 \%$ beta-mercaptoethanol) heated at $95^{\circ} \mathrm{C}$, and loaded onto a $12 \%$ SDS PAGE gel. Gels were run at $150 \mathrm{~V}$ for 2 hrs. Following electrophoresis, gels were incubated in transfer buffer (25 mM Tris, $192 \mathrm{nM}$ glycine, $15 \% \mathrm{v} / \mathrm{v}$ methanol) for $15 \mathrm{~min}$. Proteins were transferred from 1D gels to nitrocellulose membrane overnight at $30 \mathrm{~V}$ and $60 \mathrm{~V}$ for $1 \mathrm{hr}$. Following transfer, each membrane was placed in $20 \mathrm{ml}$ of blocking buffer for 1-2 hr. Blocking buffer consisted of $1 \times$ Tris-buffered saline (TBS) $5 \mathrm{~g}$ of non-fat dried milk/2.5 ml of $10 \%$ Tween. $10 \times$ TBS consisted of $24.2 \mathrm{~g}$ Tris base, $80 \mathrm{~g}$ of $\mathrm{NaCl}, \mathrm{pH}$ 7.6. Primary antibody was added in a $1 / 5000(\mathrm{v} / \mathrm{v})$ ratio of antibody to blocking buffer and the membranes were incubated overnight at $4^{\circ} \mathrm{C}$. This was followed by five 5 min washes in blocking buffer. Secondary horseradish peroxidase (HRP) conjugated antibody was added in a $1 / 1000$ ratio of antibody to blocking buffer and the membranes were incubated for 1 hr. Membranes were then washed 5 times in $1 \times$ TBS for 5 min each. Immunoreactive bands were visualized using BioRad HRP color development reagent 4-chloro-1-naphthol and the AlphaImager 950 high-performance CCD 
camera. Spot densities were quantified using AlphaImager software.

\section{D gel analysis of $H$. capsulatum isolated from IFN- activated macrophages}

Bone marrow derived macrophages were harvested 5 days following incubation with $10 \mathrm{ng} / \mathrm{ml}$ granulocyte macrophage-colony stimulating factor (GM-CSF). Macrophages were incubated for $24 \mathrm{hr}$ with $5 \mathrm{ng} / \mathrm{ml}$ of IFN- $\gamma$. Leucine uptakes assays, as previously described ${ }^{7}$, showed that macrophages were activated to inhibit $H$. capsulatum growth by $80 \%$ (data not shown). Macrophages were infected with $H$. capsulatum at a multiplicity infection of 5 for $24 \mathrm{hrs}$. Following $24 \mathrm{hr}$ incubation, macrophages were washed to remove any $H$. capsulatum that had not been ingested. Macrophages were then lysed in a buffer containing 19\%, ethanol, .1\% SDS, and 1\% phenol. An $H$. capsulatum control was also prepared under the exact conditions except for the addition of macrophages. Cells were centrifuged at $2000 \mathrm{G}$ 's and the supernatant containing macrophage debris was removed. H. capsulatum cells were washed, lysed, and 2D gel analysis was performed as previously described. In order to retrieve an adequate amount of $H$. capsulatum protein approximately $3.0 \times 10^{7}$ macrophages needed to be infected for one biological replicate.

\section{Conclusion}

Using a proteomic approach we have begun to address the knowledge gap which exists regarding the identities and number of proteins regulated by $H$. capsulatum under host conditions. Among the H. capsulatum proteins whose regulation was influenced by lowering iron availability were metabolic enzymes involved in glycolysis, lysine biosynthesis, and the TCA cycle. Like S. cerevisiae and C. ablicans $[37,40], H$. capsulatum may adjust its metabolism to more efficiently use the iron that is available. This modulation might be advantageous for survival in a nutritionally restricted environment. Recent studies have shown ferrous, but not ferric, iron maintains homoeostasis in $H$. capsulatum triacylglycerides indicating a role for lipid metabolism in relation to iron [27].

A shift in metabolism and a $2.0 \%$ reduction in protein abundance suggest that the organism is reducing the activity of expendable cellular processes to cope with environmental changes similar to those encountered in the host. Three of the H. capsulatum enzymes altered by iron levels; asparaginyl-tRNA synthetase, saccharopine dehydrogenase, and a protein with an amino acid sequence unique to $H$. capsulatum have yet to be connected to pathogen iron availability thus warranting further investigation.

\section{Competing interests}

The authors declare that they have no competing interests.

\section{Authors' contributions}

MSW designed the experiments, analyzed and interpreted data, and prepared the manuscript. DSS helped with LCMS/MS analysis, MS data interpretation, and manuscript preparation. FJG and AGS contributed by helping construct the $H$. capsulatum genomic/proteomic database. $\mathrm{MH}$ helped by performing 2D gel electrophoresis experiments. QC and BC provided ICP-MS analysis. QC also helped with data interpretation and manuscript preparation. TAN and GSD contributed to the preparation of manuscript. All authors read and approved the final manuscript.

\section{Additional material}

\section{Additional file 1}

Fold changes and $p$ values from the 42 protein spots altered in abundance following $\mathrm{H}$. capsulatum growth in media containing $5 \mathrm{M}$ apo-transferrin for 24 and $48 \mathrm{hr}$. List of $p$ values and fold changes for all of the $\mathrm{H}$. capsulatum proteins found differentially expressed when iron levels were lowered.

Click here for file

[http://www.biomedcentral.com/content/supplementary/14775956-6-36-S1.tiff]

\section{Additional file 2}

H. capsulatum malate dehydrogenase protein expression following ingestion by macrophages. Magnified region of $\mathrm{H}$. capsulatum malate dehydrogenase, spot 17 (A31) from 2D gel analysis of $\mathrm{H}$. capsulatum A.) grown in the presence of a macrophage lysis buffer $B$.) following isolation from IFN- activated bone marrow derived macrophages. Protein band outlines were created by the SameSpots software. Each biological replicate is labeled 1, 2, or 3. The MALDI-TOF and bioinformatic analysis of the in-gel digestion of this protein spot yielded a MASCOT score of 157 with 9/10 masses matched covering $45 \%$ of the of the malate dehydrogenase protein sequence.

Click here for file

[http://www.biomedcentral.com/content/supplementary/14775956-6-36-S2.tiff]

\section{Acknowledgements}

We would like to thank Michael Wagner (Cincinnati Children's Hospital Medical Center) for mass spectrometric search engine setup and helpful discussions regarding statistical analysis. Thank you to Simon L. Newman for discussions pertaining to $H$. capsulatum growth assays. $H$. capsulatum sequences for database I were generated by the group of Elaine Mardis at the Washington University St. Louis Genome Sequencing Center, in collaboration with William Goldman (Washington University St. Louis) and Anita Sil (UCSF). This work was supported by NIH grants Al-42747 and Al34361 .

\section{References}

I. Allen HL, Deepe GS Jr: Apoptosis modulates protective immunity to the pathogenic fungus Histoplasma capsulatum. J Clin Invest 2005, I I 5:2875-2885.

2. Anderson PJ: Tumor necrosis factor inhibitors: clinical implications of their different immunogenicity profiles. Semin Arthritis Rheum 2005, 34:19-22. 
3. Cano MV, Hajjeh RA: The epidemiology of histoplasmosis: a review. Semin Respir Infect 200I, 16:109-118.

4. Mandell W, Goldberg DM, Neu HC: Histoplasmosis in patients with the acquired immune deficiency syndrome. Am J Med 1986, 81:974-978.

5. Sieper J, Brande J Van Den: Diverse effects of infliximab and etanercept on T lymphocytes. Semin Arthritis Rheum 2005, 34:23-27.

6. Howard DH: Intracellular Behavior Of Histoplasma Capsulatum. J Bacteriol 1964, 87:33-38.

7. Newman SL, Gootee L, Morris R, Bullock WE: Digestion of Histoplasma capsulatum yeasts by human macrophages. J Immunol 1992, 149:574-580.

8. Lane TE, Wu-Hsieh BA, Howard DH: Iron limitation and the gamma interferon-mediated antihistoplasma state of murine macrophages. Infect Immun 199I, 59:2274-2278.

9. Eissenberg LG, Goldman WE, Schlesinger PH: Histoplasma capsulatum modulates the acidification of phagolysosomes. J Exp Med 1993, 177:1605-1611.

10. Eissenberg LG, Schlesinger PH, Goldman WE: Phagosome-lysosome fusion in P388D I macrophages infected with Histoplasma capsulatum. J Leukoc Biol 1988, 43:483-491.

11. Lane TE, Otero GC, Wu-Hsieh BA, Howard DH: Expression of inducible nitric oxide synthase by stimulated macrophages correlates with their antihistoplasma activity. Infect Immun 1994, 62: 1478-1479.

12. Nakamura LT, Wu-Hsieh BA, Howard DH: Recombinant murine gamma interferon stimulates macrophages of the RAW cell line to inhibit intracellular growth of Histoplasma capsulatum. Infect Immun 1994, 62:680-684.

13. Mattow J, Siejak F, Hagens K, Becher D, Albrecht D, Krah A, Schmidt F, Jungblut PR, Kaufmann SH, Schaible UE: Proteins unique to intraphagosomally grown Mycobacterium tuberculosis. Proteomics 2006, 6:2485-2494.

14. Becker D, Selbach M, Rollenhagen C, Ballmaier M, Meyer TF, Mann M, Bumann D: Robust Salmonella metabolism limits possibilities for new antimicrobials. Nature 2006, 440:303-307.

15. Shi L, Adkins JN, Coleman JR, Schepmoes AA, Dohnkova A, Mottaz HM, Norbeck AD, Purvine SO, Manes NP, Smallwood HS, et al.: Proteomic analysis of Salmonella enterica serovar typhimurium isolated from RAW $\mathbf{2 6 4 . 7}$ macrophages: identification of a novel protein that contributes to the replication of serovar typhimurium inside macrophages. I Biol Chem 2006, 281:29|3|-29|40.

16. Twine SM, Mykytczuk NC, Petit MD, Shen H, Sjostedt A, Wayne Conlan J, Kelly JF: In vivo proteomic analysis of the intracellular bacterial pathogen, Francisella tularensis, isolated from mouse spleen. Biochem Biophys Res Commun 2006, 345:|62 I-1633.

17. Zhou XW, Kafsack BF, Cole RN, Beckett P, Shen RF, Carruthers VB: The opportunistic pathogen Toxoplasma gondii deploys a diverse legion of invasion and survival proteins. J Biol Chem 2005, 280:34233-34244.

18. Orsborn KI, Shubitz LF, Peng T, Kellner EM, Orbach MJ, Haynes PA, Galgiani JN: Protein expression profiling of Coccidioides posadasii by two-dimensional differential in-gel electrophoresis and evaluation of a newly recognized peroxisomal matrix protein as a recombinant vaccine candidate. Infect Immun 2006, 74: $1865-1872$.

19. Kniemeyer O, Lessing F, Scheibner O, Hertweck C, Brakhage AA Optimisation of a 2-D gel electrophoresis protocol for the human-pathogenic fungus Aspergillus fumigatus. Curr Genet 2006, 49: 178-189.

20. Hwang L, Hocking-Murray D, Bahrami AK, Andersson M, Rine J, Sil A: Identifying phase-specific genes in the fungal pathogen Histoplasma capsulatum using a genomic shotgun microarray. Mol Biol Cell 2003, 14:23 I4-2326.

21. Nittler MP, Hocking-Murray D, Foo CK, Sil A: Identification of Histoplasma capsulatum transcripts induced in response to reactive nitrogen species. Mol Biol Cell 2005, 16:4792-48I3.

22. Albuquerque PC, Nakayasu ES, Rodrigues ML, Frases S, Casadevall A, Zancope-Oliveira RM, Almeida IC, Nosanchuk JD: Vesicular transport in Histoplasma capsulatum: an effective mechanism for trans-cell wall transfer of proteins and lipids in ascomycetes. Cell Microbiol 2008, 10:1695-1710.

23. Newman SL, Gootee L, Brunner G, Deepe GS Jr: Chloroquine induces human macrophage killing of Histoplasma capsula- tum by limiting the availability of intracellular iron and is therapeutic in a murine model of histoplasmosis. J Clin Invest 1994, 93:1422-1429.

24. Newman SL, Gootee L, Stroobant V, Goot H van der, Boelaert JR Inhibition of growth of Histoplasma capsulatum yeast cells in human macrophages by the iron chelator VUF 8514 and comparison of VUF 85 I 4 with deferoxamine. Antimicrob Agents Chemother 1995, 39:1824-1829.

25. Timmerman MM, Woods JP: Ferric reduction is a potential iron acquisition mechanism for Histoplasma capsulatum. Infect Immun 1999, 67:6403-6408.

26. Lane TE, Wu-Hsieh BA, Howard DH: Gamma interferon cooperates with lipopolysaccharide to activate mouse splenic macrophages to an antihistoplasma state. Infect Immun 1993, 6I:|468-|473.

27. Zarnowski R, Dobrzyn A, Ntambi JM, Woods JP: Ferrous, but not ferric, iron maintains homeostasis in Histoplasma capsulatum triacylglycerides. Curr Microbiol 2008, 57:153-I57.

28. Salamov AA, Solovyev VV: Ab initio gene finding in Drosophila genomic DNA. Genome Res 2000, 10:516-522.

29. Huang $X$, Madan A: CAP3: A DNA sequence assembly program. Genome Res 1999, 9:868-877.

30. Aylor DL, Price EW, Carbone I: SNAP: Combine and Map modules for multilocus population genetic analysis. Bioinformatics 2006, 22: I399-| 401 .

31. Ding L, Sabo A, Berkowicz N, Meyer RR, Shotland Y, Johnson MR, Pepin KH, Wilson RK, Spieth J: EAnnot: a genome annotation tool using experimental evidence. Genome Res 2004, I 4:2503-2509.

32. Birney E, Durbin R: Dynamite: a flexible code generating language for dynamic programming methods used in sequence comparison. Proc Int Conf Intell Syst Mol Biol 1997, 5:56-64.

33. Howard DH, Rafie R, Tiwari A, Faull KF: Hydroxamate siderophores of Histoplasma capsulatum. Infect Immun 2000, 68:2338-2343.

34. Hwang LH, Mayfield JA, Rine J, Sil A: Histoplasma Requires SID I, a Member of an Iron-Regulated Siderophore Gene Cluster, for Host Colonization. PLoS Pathog 2008, 4: 1000044.

35. Timmerman MM, Woods JP: Potential role for extracellular glutathione-dependent ferric reductase in utilization of environmental and host ferric compounds by Histoplasma capsulatum. Infect Immun 200I, 69:767I-7678.

36. Zarnowski R, Cooper KG, Brunold LS, Calaycay J, Woods JP: Histoplasma capsulatum secreted gamma-glutamyltransferase reduces iron by generating an efficient ferric reductant. Mol Microbiol 2008.

37. Lan CY, Rodarte G, Murillo LA, Jones T, Davis RW, Dungan J, Newport G, Agabian N: Regulatory networks affected by iron availability in Candida albicans. Mol Microbiol 2004, 53:I45I-I 469 .

38. Lian T, Simmer MI, D'Souza CA, Steen BR, Zuyderduyn SD, Jones S], Marra MA, Kronstad JW: Iron-regulated transcription and capsule formation in the fungal pathogen Cryptococcus neoformans. Mol Microbiol 2005, 55: | 452-। 472.

39. Masse $E$, Gottesman S: A small RNA regulates the expression of genes involved in iron metabolism in Escherichia coli. Proc Natl Acad Sci USA 2002, 99:4620-4625.

40. Philpott CC, Protchenko O: Response to iron deprivation in Saccharomyces cerevisiae. Eukaryot Cell 2008, 7:20-27.

4I. Allendoerfer R, Deepe GS Jr: Intrapulmonary response to Histoplasma capsulatum in gamma interferon knockout mice. Infect Immun 1997, 65:2564-2569.

42. Fish WW: Rapid colorimetric micromethod for the quantitation of complexed iron in biological samples. Methods Enzymol 1988, 158:357-364.

43. Tamarit J, Irazusta V, Moreno-Cermeno A, Ros J: Colorimetric assay for the quantitation of iron in yeast. Anal Biochem 2006, $351: \mid 49-151$. 